2011

\title{
Intervention in Libya, Yes, Intervention in Syria, No: Deciphering the Obama Administration
}

Amos N. Guiora

Follow this and additional works at: https://scholarlycommons.law.case.edu/jil

Part of the International Law Commons

\section{Recommended Citation}

Amos N. Guiora, Intervention in Libya, Yes, Intervention in Syria, No: Deciphering the Obama Administration, 44 Case W. Res. J. Int'l L. $251(2011)$

Available at: https://scholarlycommons.law.case.edu/jil/vol44/iss1/14

This Article is brought to you for free and open access by the Student Journals at Case Western Reserve University School of Law Scholarly Commons. It has been accepted for inclusion in Case Western Reserve Journal of International Law by an authorized administrator of Case Western Reserve University School of Law Scholarly Commons. 


\title{
INTERVENTION IN LIBYA*, YES; INTERVENTION IN SYRIA, NO: DECIPHERING THE OBAMA ADMINISTRATION
}

\begin{abstract}
Amos N. Guiora ${ }^{\dagger}$
Deciphering an American presidential administration is truly yeoman's work. It is still too early to judge whether the Obama Administration is significantly distinct from previous administrations. Arguably, the task should be left to historians. Nevertheless, even a casual perusal of President Obama's Middle East policy (perhaps best described as 'policy') reflects a combination of naiveté, inconsistency and murkiness. While perhaps by design, the impact-on the ground-is deeply troublesome. While domestic political considerations are a reality, the implications of the Administration's policy in an area of the world as treacherous as the Middle East are, potentially, staggering.

Precisely because international law does not articulate either normative or architectural standards as to when international humanitarian intervention is justified, national leaders arguably have a responsibility to act. The oft-cited phrase "when the cannons roar, the muses are silent" is particularly relevant to this discussion. For a variety of reasons, the international community has determined - whether actively or passively - that the massacre of the Syrian population by the Assad government does not justify international humanitarian intervention. While the human rights violations occurring on a daily basis do not compare to the horrors of Rwanda, Kosovo, or Sierra Leone they are not less compelling than the events transpiring in Libya. If, by metaphorical analogy, the international community is the cannons and the U.S. is the muse; does that mean that the Obama Administration is required to be silent? After all, if the quote were to be rigorously applied, then many of the institutions created to minimize human suffering would neither exist, much less function in wartime. While the distinction-from the perspective of international humanitarian intervention-

* Gadhafi was killed in his hometown of Sirte in October 2010. Neil MacFarquhar, An Erratic Leader, Brutal and Defiant until the End, N.Y. TIMES, Oct. 21, 2011, at A16.

$\dagger$ Professor of Law, S.J. Quinney College of Law, the University of Utah; I would like to thank the editors of the Case Western Reserve University School of Law, Journal of International Law and Professor Michael Scharf for their gracious invitation to participate in the aptly named conference "International Law in Crisis" (September, 2011). I have presented some of the themes suggested in this article in meetings and conferences in the US, Europe and Israel. I would like to thank Jacqueline Neal Esty (SJ Quinney College of Law, JD expected 2012) and Kennedy Davis Nate (SJ Quinney College of Law, JD expected 2012) for their invaluable research and editing assistance.
\end{abstract}


between Libya and Syria is as unclear as the criteria that justifies intervention; that must not serve as a misguided basis for the Obama Administration to largely turn its back on the Syrian people.

I. INTRODUCTION ............................................................... 252

II. INTERVENTION: A BRIEF SURVEY .............................................254

III. THE MIDDLE EAST TODAY .................................................... 258

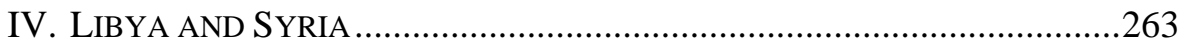

V. LAW OF HUMANITARIAN INTERVENTION ................................... 271

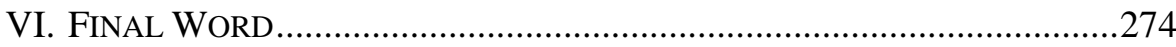

\section{INTRODUCTION}

Deciphering an American presidential administration is truly yeoman's work. Whether the Obama Administration is significantly distinct from previous administrations is too early to judge. Arguably, the task should be left to historians. Nevertheless, even a casual perusal of President Obama's Middle East policy (perhaps best described as 'policy') reflects a combination of naiveté, inconsistency and murkiness. ${ }^{1}$ While perhaps by design, the impact - on the ground - is deeply troublesome. While domestic political considerations are a reality, the implications of the Administration's policy in an area of the world as treacherous as the Middle East are, potentially, staggering. ${ }^{2}$

President Obama's policy (assuming a coherent policy exists) has been particularly problematic on two distinct fronts: inconsistency in determining under what conditions intervention is justified and a sharp dissonance between suggested expectations and actual delivery. ${ }^{3}$ The latter is

1 Compare Douglas J. Feith \& Seth Cropsey, The Obama Doctrine Defined, CommEnT., July-Aug. 2011, at 11, available at http://www.commentarymagazine.com/article/theobama-doctrine-defined/ ("The United States under Barack Obama is less assertive, less dominant, less power-minded, less focused on the American people's particular interests, and less concerned about preserving U.S. freedom of action."), with Fareed Zakaria, Should U.S. Foreign Policy Be One-Size-Fits-All?, CNN (July 10, 2011), http://globalpublicsquare.blogs. cnn.com/2011/07/10/should-u-s-foreign-policy-be-one-size-fits-all/ (discussing consistency in U.S. foreign policy in the Middle East).

2 See Barbara Slavin, Keeping up with Mideast Changes, New AtLAnTICIST: PoL'y AND ANALYSIS BLOG (July 6, 2011), http://www.acus.org/new_atlanticist/keeping-mideastchanges?utm_source=feedburner\&utm_medium $=$ email\&utm_campaign $=$ Feed $\% 3 \mathrm{~A}+$ new atlanticist+\%28New+Atlanticist $\% 29$ (providing an alternative analysis on the political considerations of the Middle East).

3 See Glenn Greenwald, U.S. More Unpopular in the Arab World than Under Bush, SALON (July 13, 2011, 8:14 AM), http://www.salon.com/news/middle_east/index.html? story=/opinion/greenwald/2011/07/13/arabs (stating "anti-American sentiment is now at dangerously — even unprecedentedly_high levels.”). 
most clearly demonstrated both in the President's Cairo speech ${ }^{4}$ and his May 19, 2011 talk in which he called on Israel to return to the 1967 (pre Six Day War) borders. ${ }^{5}$ In the former, President Obama overtly suggested a distinct change forthcoming in U.S. policy regarding the Israel-Palestinian conflict; the failure to 'deliver' has led to extraordinary disappointment amongst Palestinians who assumed change was in the offing. ${ }^{6}$ Arguably, the Palestinian demand for declaration of Palestinian statehood by the U.N. General Assembly is a direct result of disappointment with the President's failure to 'deliver' the suggested change.

With respect to the second example, the President's speech reflected the oft-used expression in college basketball referring to a student-athlete who leaves college after his freshman year for the NBA: "one and done."7 Simply put: the President's speech was absolutely lacking in any follow-up ${ }^{8}$ as neither details nor the identity of a new Peace Negotiator ${ }^{9}$ were revealed. That lack of detail, particularly in the aftermath of the Cairo and Washington, D.C. speeches, which hinted at significant policy movement and direction, has directly contributed to inconsistent policy articulation and development. That inconsistency is particularly evident when comparing the decision to intervene militarily in Libya ${ }^{10}$ with the decision to not intervene in Syria.

While perhaps the inconsistency is predicated on careful geopolitical analysis, the Administration's actions raise questions regarding the essence of intervention, regardless of whether it is predicated on military or

4 President Barack Obama, Remarks by the President on a New Beginning at Cairo University (June 4, 2009) [hereinafter New Beginning Speech] (discussing a "new beginning" between Muslims and the U.S.)

5 President Barack Obama, Speech on the Middle East (May 19, 2011) [hereinafter Middle East Speech].

6 See, e.g., Dan Ephron, The Wrath of Mahmoud Abbas, DAILy BEAST (Apr. 24, 2011, 10:26 PM), http://www.thedailybeast.com/articles/2011/04/25/mahmoud-abbas-interviewpalestinian-leaders-frustration-with-obama.html (stating that President Obama, "who seemed open to helping the Palestinian cause before his election, quickly cooled once he got into office - and at a crucial moment, betrayed [Mahmoud Abbas].").

7 Middle East Speech, supra note 5 (discussing negotiations for "a viable Palestine, a secure Israel.").

8 The speech he gave at AIPAC on May 22, 2011 does not qualify as follow-up. See President Barack Obama, Remarks by the President at the AIPAC Policy Conference 2011 (May 22, 2011).

9 According to unconfirmed press reports, previous Peace Negotiator George Mitchell's retirement was largely owing to his frustration with Israeli Prime Minister Netanyahu. See Nathan Guttman, Mideast Envoy George Mitchell Resigns, Amid Frustration, Turf Wars, THE JEWISH DAILY FORWARD (May 13, 2011), http://www.forward.com/articles/137797/.

10 See President Barack Obama, Remarks by the President in Address to the Nation on Libya (Mar. 28, 2011) (discussing the concern for limiting refugee flows into Tunisia and Egypt, while refraining from a direct attack against Gadhafi). 
humanitarian considerations. It is essential to underscore that interventionthe theme of this essay-defines the historic relationship between Western powers and the Middle East. A brief historical recounting of that specific relationship is telling; however, it is important to add that Western intervention has largely defined the relationship between the West and non-Western peoples in general.

To facilitate an understanding of the Obama Administration's Middle East policy through the lens of the intervention/non-intervention dilemma, this article will be divided as follows: Section Two is a brief survey of Western intervention in the Middle East; Section Three is a survey of recent Middle East events; Section Four is an analysis of U.S. policy in Libya and Syria; Section Five is a discussion of the law of international humanitarian intervention; and Section Six is 'Looking Forward'.

\section{INTERVENTION: A BRIEF SURVEY}

Whether through colonization, military, or humanitarian intervention, Western intervention in the Middle East has, in many ways, defined the relationship between the West and the Middle East. At one time or another Western powers have had a significant presence in Palestine (British Palestine Mandate, 1917-1948), ${ }^{11}$ Lebanon (France 1920-1946; U.S. 1958), ${ }^{12}$ Syria (France 1920-1946), ${ }^{13}$ Jordan/Transjordan (U.K. 19221946), ${ }^{14}$ Libya (France 1942-1951), ${ }^{15}$ Iran (U.K. 1941-1945) ${ }^{16}$ Iraq (British Mandate of Mesopotamia 1920-1932, ${ }^{17}$ U.S. 2003-present),${ }^{18}$ Afghanistan

11 A History of Conflict, BBC NEws, http://news.bbc.co.uk/2/shared/spl/hi/middle_east/03/ v3_ip_timeline/html/1917.stm (last visited Jan. 3, 2012); A History of Conflict, BBC, http:// news.bbc.co.uk/2/shared/spl/hi/middle_east/03/v3_ip_timeline/html/1948.stm (last visited Jan. 3, 2012).

12 Mitchell Bard, Modern Lebanon, Jewish VIRTUAL LiBRARY, http://www.jewishvirtual library.org/jsource/arabs/modleb.html (last visited Jan. 3, 2012); Timeline: Lebanon, BBC NEWS (July 13, 2011), http://news.bbc.co.uk/2/hi/middle_east/819200.stm (providing a timeline of Lebanon's history from 1920 to June 2011).

13 Timeline: Syria, BBC NEws, http://news.bbc.co.uk/2/hi/middle_east/country_profiles/ 827580.stm (providing a timeline of Syria's history from 1918 to August 2011).

14 Background Note: Jordan, U.S. DEP'T OF STATE (Mar. 25, 2011), http://www.state.gov/ $\mathrm{r} / \mathrm{pa} / \mathrm{ei} / \mathrm{bgn} / 3464 . \mathrm{htm}$ (providing information regarding Jordan's geography, people and history).

15 Timeline: Libya, BBC News (May 21, 2011), http://news.bbc.co.uk/2/hi/africa/1398 437.stm (providing a timeline of Libya's history from $7^{\text {th }}$ Century BC through October 2011).

16 Background Note: Iran, U.S. DEP'T OF STATE (Feb. 17, 2011), http://www.state.gov/r/ $\mathrm{pa} / \mathrm{ei} / \mathrm{bgn} / 5314$.htm (providing information about Iran's geography, history and government).

17 David R. Woodward, The Middle East During World War One, BBC News (Mar. 10, 2011), http://www.bbc.co.uk/history/worldwars/wwone/middle_east_01.shtml (providing a timeline of key events in the Middle East during and after World War One). 
(U.K. 1839-1919, U.S.S.R. 1980-1989, U.S. 2001-present), ${ }^{19}$ and the United Arab Emirates (U.K. 1819-1968). ${ }^{20}$ The principle of intervention raises profound questions regarding both the limits of national sovereignty and articulation of national self-interest. ${ }^{21}$ Needless to say, what is defined as intervention can also be described as imperialism (as evidenced in many of the aforementioned cases of Western intervention in the Middle East); after all, Western powers have historically perceived Middle East oil and trade routes as essential to their national interests and have, therefore, imposed themselves on indigenous populations. ${ }^{22}$

The historical basis for Western imperialism was, largely, a combination of: availability of much needed natural resources; cheap labor; geopolitics; and Christian missionaries. ${ }^{23}$ The result was both taking (natural resources) and purported giving (Christianity and democratic values). ${ }^{24}$ The intended beneficiary was the Western power; in large part, the indigenous people were enormously victimized. That said, some have suggested Western powers also contributed to local cultures by introducing democratic values and traditions, but the grim tale of post-colonial Africa suggests a significantly different reality.

One of the clear results of World War II is the dusk that settled on traditional Western powers; while the sun (as the expression went) never set on the British Empire, since World War II, the U.K. has become almost exclusively domestic-focused (this incorporates the 'troubles' in Northern Ireland) and France has largely disengaged (following withdrawals from Algeria, Vietnam and Lebanon) from any international involvement. The post-World War II dawn was largely dominated by the Cold War (until the

18 Iraq Timeline, BBC NEws (May 21, 2011), http://news.bbc.co.uk/2/hi/middle_east/ 737483.stm (providing a timeline of key events in Iraqi history from 1534 through April 2011).

19 Afghanistan-Timeline, BBC News (Mar. 15, 2011), http://news.bbc.co.uk/2/hi/116210 8.stm (providing a timeline of Afghanistan's history from 1919 to February 2011); Background Note: Afghanistan, U.S. DEP'T OF STATE (Dec. 6, 2010), http://www.state.gov/ $\mathrm{r} / \mathrm{pa} / \mathrm{ei} / \mathrm{bgn} / 5380 . \mathrm{htm}$ (providing information regarding Afghanistan's geography, population and history).

20 Background Note: United Arab Emirates, U.S. DeP'T of STATE (Mar. 16, 2011), http://www.state.gov/r/pa/ei/bgn/5444.htm (providing information regarding the history, population and geography of the United Arab Emirates).

21 Marc Trachtenberg, Intervention in Historical Perspective, in 1 EMERGING NORMS OF JustifiEd INTERVENTION 7, 8 (Carl Kaysen \& Laura Reed, eds., 1993) (discussing foreign state intervention in the "internal affairs of independent states . ...").

22 For more on imperialism, see David Anderson, It's Not Just Kenya. Squaring Up to the Seamier Side of Empire is Long Overdue, THE GUARDIAN (July 25, 2011), http://www. guardian.co.uk/commentisfree/2011/jul/25/kenya-empire-mau-mau-britain?INTCMP= SRCH.

23 Id.

$24 I d$. 
fall of the Berlin Wall in 1989), as the U.S. and U.S.S.R. (until its fall in 1991) largely 'divided' the world into two (with the exception of nonaligned nations) spheres of influence with extraordinary, but ultimately restrained, competition for geo-political gains.

From an American perspective, the desire to achieve a particular regional gain often resulted in the U.S. supporting unsavory regimes and lead$\mathrm{ers}^{25}$ for the sole purpose of denying the Soviet Union a perceived gain. ${ }^{26} \mathrm{In}$ the Cold War context, "victory" was piecemeal (if at all), largely limited by the doctrine of mutual assured destruction (MAD), and mainly devoid of principle other than perceived gain (however defined) at the expense of the other side.

The obsession with the other side led both the U.S. and U.S.S.R. to costly military interventions; Brezhnev's decision to invade Afghanistan $(1979)^{27}$ was arguably the beginning of the end of the U.S.S.R., and the Kennedy-Johnson ${ }^{28}$ decision to deploy the U.S. military to Vietnam (early 1960's) continues to have a dramatic impact on the U.S. budget, psyche and armed forces. In both cases, the U.S. and U.S.S.R. intervened in a conflict that was 'not theirs.' Soldiers were sent to countries whose language, culture and conflict were foreign to the ordinary soldier, whose mission (other than to stay alive) was unarticulated beyond vague and confused rhetoric.

Unfortunately, the vagueness of overseas missions continues to haunt U.S. policy makers to this day: a talk before cadets at the U.S. Military Academy ${ }^{29}$ reinforced that the mission in Iraq $^{30}$ was as unclear and vague to today's military officers as it was to their predecessors in Vietnam

25 President Franklin D. Roosevelt's oft-cited phrase referring to a Latin America dictator, "[h]e may be a son of a bitch, but he's our son of a bitch," is particularly apt in this context; arguably, that philosophy continues to define U.S. relations with world leaders. See THE OXFORD DICTIONARY OF AMERICAN QUOTATIONS 268 (Hugh Rawson \& Margaret Miner eds., Oxford Univ. Press 2006) (1997).

26 See generally JAmes M. ScotT, DeCiding to InTERvene: The REAGAn DoctRine AND AMERICAN FoREIGN POLICY (1996) (noting the Reagan Doctrine and the push to keep gains from the Soviet Union through interventions in Nicaragua, Iran, Angola, and El Salvador).

27 See The Soviet Experience in Afghanistan: Russian Documents and Memoirs, in 2 AFGHANISTAN: LESSONS FROM THE LAST WAR (Svetlana Savranskaya ed., 2001), available at http://www.gwu.edu/ nsarchiv/NSAEBB/NSAEBB57/ (explaining that fears that Afghan Prime Minister Hafizullah Amin would turn towards the U.S., as Egyptian President Sadat had previously done, helped fuel the decision to invade Afghanistan).

28 See generally WAR AND Public HeAlth 332 (Barry S. Levy \& Victor W. Sidel eds., 2d ed. 2008) (explaining some of the repercussions of the Vietnam War still experienced in the United States today).

29 I was greatly honored by an invitation to speak at the U.S. Military Academy in November, 2005

30 Many of the cadets I spoke to would later be tasked with commanding ground forces in Iraq. 
a mere forty years earlier. ${ }^{31}$ Doubtlessly, a similar talk to Soviet cadets in 1980 would have resulted in the same ambiguity regarding their mission in Afghanistan; that conflict, ultimately, demonstrated the Red Army was little more than a brutal paper tiger. ${ }^{32}$

That said, military intervention can also occur for humanitarian purposes; NATO intervention (albeit after much tragedy and atrocity) in the former Yugoslavia is a clear example, ${ }^{33}$ as is U.S. intervention in Haiti. ${ }^{34}$ The philosophy behind humanitarian intervention is simple: it stems from the principle that "intervention for human protection purposes . . is supportable when major harm to civilians is occurring or imminently apprehended, and the state in question is unable or unwilling to end the harm, or is itself the perpetrator." 35 In other words, humanitarian intervention is based on the belief that "when a government turns savagely upon its own people ..." it becomes the responsibility of "[a]ny state capable of stopping the slaughter ... to try to do so." 36

Despite the relatively recent use of the term "humanitarian intervention," modern history is replete with examples of such intervention. Some of the earliest occurrences of humanitarian intervention extend back to the nineteenth century, with the notable interventions by the United Kingdom, France, and Russia in Syria, Naples, and Greece to prevent local governments from murdering citizens of the respective countries. ${ }^{37}$ Since that time period, other notable humanitarian interventions include Belgian intervention in the Congo (1960), ${ }^{38}$ French intervention in Central Africa (1979), ${ }^{39}$

31 See J. William Fulbright, The Arrogance of Power 106-07, 110 (1966) ("In Vietnam the United States is fighting virtually alone and for vague purposes in a war which is not an international conflict but an insurrection in one part of a divided country supported by the other part.").

32 That "spirit" of brutality largely defines the conduct of the Russian Army in the Chechnya conflict. Amos N. GuiORA, Global PERSPECTIVES ON COUNTERTERRORISM 74-81 (Aspen Publishers, 2nd ed. 2011).

33 See Ian Bankroft, Serbia's Anniversary is a Timely Reminder, THE GUARDIAN (Mar. 24, 2009), http://www.guardian.co.uk/commentisfree/2009/mar/24/serbia-kosovo.

34 See Douglas Jehl, Mission to Haiti: In Washington; Clinton Says U.S. Will Deter Abuses by Haiti Police, N.Y. TIMES (Sept. 22, 1994), http://www.nytimes.com/1994/09/22/world/ mission-to-haiti-in-washington-clinton-says-us-will-deter-abuses-by-haiti-police.html? scp= $4 \&$ sq $=$ haiti $+\& s t=$ nyt.

35 InT'L COMmission ON INTERVENTION AND STATE SOVEREIGNTY, THE RESPONSIBILITY TO PROTECT 16 (2001), available at http://responsibilitytoprotect.org/ICISS\%20Report.pdf.

36 Michael Walzer, Just and UnJust Wars: A Moral ARgument with Historical ILLUSTRATIONS 101, 108 (4th ed. 2006).

37 Peter MalancZuK, Humanitarian InTERVENTION AND the USE OF ForCE 8 (1993).

38 InT'L COMMISSION ON INTERVENTION AND STATE SOVEREIGNTY, THE RESPONSIBILITY TO PROTECT: SUPPLEMENTARY VOLUME 49-51 (2001).

39 Id. at 63-64. 
U.S. intervention in Somalia (1992-1993), ${ }^{40}$ and the previously cited NATO intervention in the former Yugoslavia (1999). ${ }^{41}$

\section{THE MIDDLE EAST TODAY}

In the not too distant past, the term "Middle East" referred to a limited number of countries, including Egypt, Iraq, Israel, Jordan, Lebanon, Saudi Arabia and Syria. Today, the term incorporates an extraordinary broad swath of land stretching from the edge of North Africa to the "traditional' Middle East, to the Persian Gulf, to Turkey, to the Caucus Mountains, to Afghanistan and possibly Pakistan. ${ }^{42}$ From a geographical perspective this 'crescent' (the reference is to physical parameters only) is the new Middle East that includes $4.34 \%$ of the earth's physical territory ${ }^{43}$ and $3.35 \%$ of the world's population. ${ }^{44}$ Included in this crescent are a significant number of contemporary national and international conflicts such as those in Afghanistan, Iraq, the civil war in Libya, ${ }^{45}$ the massacre of Syrian citizens by the Syrian government, ${ }^{46}$ the continued Israeli-Palestinian conflict, ${ }^{47}$ unrest in Yemen, ${ }^{48}$ riots in Jordan, ${ }^{49}$ and Iran's attempts to join the club of

$40 \quad I d$. at 94.

41 Id. at 89-94.

42 What is the Middle East?, TEACHMIDEAST, http://teachmideast.org/essays/27-geography 151-what-is-the-middle-east (last visited Jan. 3, 2012) (explaining the expansion of the Middle East).

43 The World Factbook, CIA, https://www.cia.gov/library/publications/the-world-factbook/ rankorder/2147rank.html (last visited Oct. 24, 2011) (demonstrating that the Middle East comprises 6,468,951 square km to be compared to the Earth's total 148,940,000 square km).

442011 World Population Data Sheet, Population Reference Bureau 7-8 (2011), http://www.prb.org/pdf11/2011population-data-sheet_eng.pdf (presenting the Middle East's population of approximately $238,000,000$ to be compared with the world's total population of roughly seven billion).

45 See C.J. Chivers, Libyan Rebels Gain Inches Toward Link to Tripoli, N.Y. TIMES (July 6, 2011), http://www.nytimes.com/2011/07/07/world/africa/07rebels.html?_r=1\&ref=world.

46 See generally Deborah Jerome, Syrian Regime's Unsteady Hand, COUNCIL ON ForeIGN RELATIONS (July 6, 2011), http://www.cfr.org/syria/syrian-regimes-unsteady-hand/p25429 (providing background of the massacre of Syrian citizens by the Syrian government); see also Anthony Shadid, Restive City of Hama Tests Will of Syrian Government, N.Y. TIMES (July 5, 2011), http://www.nytimes.com/2011/07/06/world/middleeast/06syria.html?pagewan ted=all

47 Concrete International Intervention Needed in Israeli-Palestinian Conflict-UN Envoy, UN NEws CENTRE (Feb. 24, 2011), http://www.un.org/apps/news/story.asp?NewsID=37614 $\& \mathrm{Cr}=$ Palestin\&Cr1\# (noting the need to continue peace talks in the Israeli-Palestinian conflict).

48 Including the emergence of al-Qaeda Arabian Peninsula and the threat it poses both to Yemen and Saudi Arabia; to that end, the US has defined the head of AQAP, Nasir alWuhayshi, as a legitimate target and has reportedly conducted drone attacks targeting AQAP operatives in Yemen. AQAP Leader Killed in U.S. Drone Attack in Yemen, YEMEN POST, http://yemenpost.net/Detail123456789.aspx?ID=3\&SubID=4180\&MainCat=3 (last updated 
nuclear nations (which, includes, in this broadened region: Israel, Pakistan, and India). ${ }^{50}$

This short list does not include - arguably - the most dramatic event of the past year: the so-called "Arab Spring," matic resignation of President Hosni Mubarak and the resulting uncertainty regarding the future face of Egypt. While elections previously scheduled for September 2011 have been postponed to the late fall, ${ }^{52}$ it is an open question whether they will be held and how the domestic political map of the Arab world's largest country will be re-aligned. One of the most important, albeit unanswered, questions is the future role of the Muslim Brotherhood ${ }^{53}$ and its impact both domestically and with respect to the Egyptian-Israel Peace Treaty. ${ }^{54}$ While some commentators were extraordinarily optimistic in the wake of Mubarak's downfall, ${ }^{55}$ others suggested a "wait and see" attitude, ${ }^{56}$

Oct. 15, 2011) (documenting U.S. drone attacks that killed eight AQAP members in Azzan, Shabwa).

49 See generally Ranya Kadri, Ethan Bronner \& Thom Shanker, Riot Police In Jordan Clear Camp Of Protesters, N.Y. Times, Mar. 26, 2011, at A8 (discussing the Jordan riots and their background).

50 See Iran's Nuclear Program, N.Y. Times (June 8, 2011), http://topics.nytimes.com/top/ news/international/countriesandterritories/iran/nuclear_program/index.html; David E. Sanger \& William J. Broad, Survivor of Attack Accelerates Iran's Effort to Produce Nuclear Material, N.Y. TIMES, July 23, 2011, at A4 (describing Iran's intention to triple its fuel production, putting it closer to bomb construction).

51 See generally Jack A. Goldstone, Understanding the Revolutions of 2011, 90 FOREIGN AFF. 8 (2011) (discussing the "Arab Spring" and Middle Eastern autocracies, and expressing optimism for democracy's development in the region).

52 See Mariam Fam \& Abdel Latif Wahba, Egypt Postpones Elections, Purges Police Following Protests, BLOOMBERG (July 13, 2011), http://www.bloomberg.com/news/2011-0713/egypt-postpones-elections-purges-police-following-protests.html.

53 See Anthony Shadid, Egypt's Islamists Show Their Might in Numbers, Demanding Religious Law, N.Y. TIMES, July 30, 2011, at A4 (describing the sudden rise of Islamism in Egypt, and noting the Muslim Brotherhood's presence among a spectrum of religious movements).

54 Camp David Accords, 17 I.L.M. 1463, 1466-74, (September 17, 1978) available at http://www.mfa.gov.il/MFA/Peace+Process/Guide+to+the+Peace+Process/Camp+David+Ac cords.htm; See Peace Treaty Between Israel and Egypt, Israel-Egypt, 17 I.L.M. 362, 362-66, (Mar. 26, 1979) available at http://www.mfa.gov.il/MFA/Peace\%20Process/Guide\%20 to $\% 20$ the $\% 20$ Peace $\% 20$ Process/Israel-Egypt $\% 20$ Peace\%20Treaty.

55 See, e.g., Nicholas D. Kristof, We Are All Egyptians, N.Y. TIMES, Feb. 4, 2011, at A23 (quoting several wounded, yet optimistic, protestors who continued to stand against the $\mathrm{Mu}$ barak regime).

56 See Richard N. Haass, The Arab Spring Has Given Way to a Long, Hot Summer, FiN. TiMES (July 6, 2011), available at http://www.cfr.org/middle-east/arab-spring-has-givenway-long-hot-summer/p25426?cid=rss-fullfeed-the_arab_spring_has_given_way_070611 \&utm_source=feedburner\&utm_medium $=$ email\&utm_campaign $=$ Feed $\% 3 \mathrm{~A}+\mathrm{cfr} \_$main $+\% 28$ CFR.org+-+Main+Site+Feed\%29 (assessing the current state of Middle Eastern countries and the need for onlookers to allow time to pass to determine the outcome). 
particularly given Egypt's importance, extending beyond its enormous military. ${ }^{57}$

In addition, a number of regional (broadly defined) hotspots deserve careful vigilance by U.S. policymakers; in particular, Pakistan, whose duplicitous "double game" is of particular concern. ${ }^{58}$ While ostensibly an American ally, the Pakistani government ${ }^{59}$ provided Osama Bin Laden with "cover"; the fact that the U.S. apparently did not notify Pakistan of the impending violation of Pakistani sovereignty is indicative of the Obama Administration's - justified - deep mistrust of Islamabad. This is particularly troublesome for all the obvious reasons: many terrorist attacks that occur in India are Pakistani linked, funded, and supported ${ }^{60}$ northwest Pakistan is a Taliban stronghold and significant concerns rightly exist regarding the security of Pakistan's nuclear arsenal should the regime fall.

Similarly, concerns have been raised regarding Turkey; a mere glance at a map of the world reinforces the extraordinary geo-political significance of the country that straddles Europe and Asia. The domestic push and pull regarding 'Turkey to where' was exacerbated by the European Union's short-sighted decision to deny Turkey membership; ${ }^{61}$ an increasing look to the Arab world was the inevitable result. President Erdogan's reelection ${ }^{62}$ suggested Turkey's further distancing from Europe and the U.S. in part because of President Obama's criticism of significant Turkish in-

57 See generally Egypt Military Strength Detail by the Numbers, GLOBALFIREPOWER.COM, http://www.globalfirepower.com/country-military-strength-detail.asp?country_id=Egypt (last updated June 30, 2011) (providing general information regarding Egypt's military might); For comparison purposes, see 2011 World Military Strength Ranking, GLOBALFIREPOWER.C OM http://www.globalfirepower.com/ (last visited Jan. 5, 2012) (ranking of global military powers, Egypt ranks 16, Saudi Arabia ranks 26, Syria ranks 35, Iraq ranks 36, Libya ranks 39, Jordan ranks 43, and Lebanon ranks 52 in the world).

58 See Lawrence Wright, The Double Game; The Unintended Consequences of American Funding in Pakistan, NEW YORKER, May 16, 2011, at 91.

59 See Jayshree Bajoria, The ISI and Terrorism: Behind the Accusations, CounCIL ON FOREIGN REL., http://www.cfr.org/pakistan/isi-terrorism-behind-accusations/p11644 (last updated May 4, 2011) (describing the possibly independent involvement of the Inter-Services Intelligence in aiding Osama bin Laden and al-Qaeda).

60 See, e.g., Mumbai Terror Group had Links with Pakistan Intelligence, Chicago Trial Told, THE GuARDIAN (May 23, 2011), http://www.guardian.co.uk/world/2011/may/23/ mumbai-terror-pakistani-intelligence-headley (discussing the potential links between the 2008 Mumbai terrorist attacks and Pakistan's intelligence agency).

61 The Turkish Republic, Recent Developments, COUNTRIESQUEST.COM, http://www. countriesquest.com/middle_east/turkey/history/the_turkish_republic/recent_developments.htm (last visited Jan. 3, 2012).

62 See Erdogan's Landslide, ECONOMIST, June 16, 2011, at 16 (urging "statesmanship" despite the ruling party's near $50 \%$ majority). 
volvement in the 2010 Gaza Flotilla $^{63}$ which dramatically impacted longstanding relations between Turkey and Israel. ${ }^{64}$ In addition, concern was raised in many circles regarding the possible strengthening of ties between Turkey and Iran. ${ }^{65}$ However, the influx of Syrian refugees ${ }^{66}$ into Turkey and the alleged presence of Iranian forces ${ }^{67}$ in Syria assisting the Syrian government massacre civilians has apparently forced Turkey to re-evaluate its relationship both with Syria and Iran. While not suggesting Turkey will reengage with the West, it does hint at a re-assessment of where Turkish interests best lie.

Saudi Arabia's vulnerability produces constant anxiety in the U.S., given U.S. dependence on Saudi oil. ${ }^{68}$ The continued dependence on oil consumption and by extension on Saudi Arabia and the Emirates is one of the great failings of $20^{\text {th }}$ century technology. That dependence and the inability to develop alternative energy sources place the U.S. in a particularly precarious position. While the Saudi military is largely dependent on the

63 See Gaza Aid Flotilla Attack: Obama Speaks to Turkey, TelegraPH (June 2, 2010), http://www.telegraph.co.uk/news/worldnews/middleeast/palestinianauthority/7795665/Gazaaid-flotilla-attack-Obama-speaks-to-Turkey.html (expressing Obama's condolences over the deaths on the Turkish ships and affirming the importance of finding ways to help the people of Gaza without undermining Israel's security); see generally Gaza Flotilla Ship Welcomed Back to Turkey by Thousands of Activists, GuARDIAN (Dec. 26, 2010), http://www.guardian. co.uk/world/2010/dec/26/gaza-flotilla-ship-returns-turkey (contrasting the planned 2011 Gaza Flotilla in which Turkey was not involved); see also Barak Ravid, Turkish Ship Involved in Gaza Flotilla Raid Pulls out of Next Convoy, Truth FREQUENCy News (June 17, 2011), http://truthfrequencynews.com/?p=51491.

64 Turkey was often referred to as Israel's only friend in the Middle East. For ramifications to Turkish-Israel relations as a result of the 2010 Gaza Flotilla, see Joshua Mitnick \& Scott Peterson, Will Gaza Flotilla Raid Mark End of Turkey-Israel Relations?, CHRISTIAN SCIENCE MONITOR (June 7, 2010), http://www.csmonitor.com/World/Middle-East/2010/0607/WillGaza-flotilla-raid-mark-end-of-Turkey-Israel-relations; see also Nichole Sobecki, Will Turkey Sever Ties with Israel?, GlobaLPost (July 17, 2010), http://www.globalpost.com /dispatch/turkey/100717/will-turkey-sever-ties-israel.

65 Diana Gregor, Strengthening Turkish-Iran Relations Risk UN Sanctions Against the Islamic Republic, RÉALITÉ-EU (Oct. 27, 2011), http://www.realite-eu.org/site/apps/nlnet /content3.aspx? $=9 \mathrm{dJBLLNkGiF} \& \mathrm{~b}=2315291 \& \mathrm{ct}=8104207 ; \quad$ Iran, Turkey, Azerbaijan Strengthen Ties, TEHRAN TIMES (Apr. 18, 2011), http://www.tehrantimes.com/index_View. asp? code $=238868$.

66 Ayla Albayrak, Refugees From Syria Stream Into Turkey, Wall St. J., at A9; More Than 1,000 Syrians Refugees Stream into Turkey Fearing a Massacre, THEJOURNAL.IE (June 9, 2011), http://www.thejournal.ie/more-than-1000-syrians-refugees-stream-into-turkey-fear ing-a-massacre-152624-Jun2011/.

67 See Merc, Deja Vu All Over Again, Middle East Reality Check Blog (June 14, 2011 8:20 AM), http://middleeastrealitycheck.blogspot.com/2011/06/deja-vu-all-over-again.html (reporting claims of Iranian involvement in Syria's crackdown).

68 See Tom Doggett, RPT-US Nov Oil Imports from Saudi Arabia Up 32 pct-EIA, REUTERS (Jan. 29, 2011), http://af.reuters.com/article/energyOilNews/idAFN282842972011 0129. 
U.S., ${ }^{69}$ it is an open question as to how it would respond in genuine crises. If the 1979 response to the takeover of the Grand Mosque in Mecca by 500 religious extremist opponents of the Saudi regime is any indication, ${ }^{70}$ American policymakers have legitimate cause for deep concern regarding the Saudi regime's ability to withstand significant internal or external threats.

Moreover, it is unclear what threat al Qaeda in the Arabian Peninsula (AQAP), which has established a powerful foothold in Yemen, poses to the Saudi regime. ${ }^{71}$ While future operational goals of al Qaeda's new leadership are presently unclear, bin Laden believed the Saudi regime to be a legitimate target because of the presence of the infidel on sacred soil. ${ }^{72}$

Finally, the danger posed by Iran, both regionally and globally, is extraordinary. Iran under the Shah was a brutal and repressive regime which brooked no dissent. However, unlike the current regime, which is similarly brutal and repressive,$^{73}$ the Shah neither threatened the region nor the world. Over the past thirty years the Ayatollah regime has done both, arguably with the worst to come. A brief survey is telling: presence of Iranian forces in Syria $;{ }^{74}$ massive supplying of arms to Hezbollah through Syria, the classic proxy nation; ${ }^{75}$ providing arms to Hamas; ${ }^{76}$ efforts to undermine the Mubar-

69 See Adam Levine, US Plans $\$ 60$ Billion, 20-year Arms Deal with Saudi Arabia, CNN (Oct. 20, 2010), http://articles.cnn.com/2010-10-20/us/us.saudi.arms.deal_1_military-edgedefense-security-cooperation-agency-sale?_s=PM:US (describing the military and arms relationship between the U.S. and Saudi Arabia).

70 See Mecca, GLOBALSECURITY.ORG, http://www.globalsecurity.org/military/world/gulf/ mecca.htm (last visited Jan. 4, 2012); Saudi Arabia: Threats to Internal Security, http://www.country-data.com/cgi-bin/query/r-11664.html (last visited Jan. 4, 2012).

71 Scott Atran, How Killing Awlaki Affects America, Al Qaeda, and the Arab Spring, HuFFingTON POST (Oct. 1, 2011), http://www.huffingtonpost.com/scott-atran/how-killingawlaki-affect_b_990182.html.

72 See generally Ahmed S. Hashim, The World According to Usama Bin Laden, 54 NAVAL WAR C. REV. 11, (2001) (discussing Osama Bin Laden's rise to "supervillian" prominence over Saddam Hussein); see also Bid Laden's Fatwa, PBS OnLINE Newshour (May 15, 2007), http://www.freerepublic.com/focus/f-news/1834249/posts (presenting bin Laden's future "war" against the U.S.).

73 See Mark D. Wallace, Iran's Execution Binge, L.A. Times (July 6, 2011), http://articles.latimes.com/2011/jul/06/opinion/la-oe-wallace-cranes-iran-20110706 ("Iran's leadership has cracked down hard, instituting a brutal campaign of terror against its own people. The most gruesome manifestation of this repression has been a wave of public executions.").

74 See Amro Ahmad, Iranian Forces in Syria to Help al-Assad Opposition, AsHARQ Alawsat (May 16, 2011), http://www.asharq-e.com/news.asp?section=1\&id=25193.

75 See Esther Pan, Syria, Iran, and the Mideast Conflict, CouncIL ON Foreign Relations (July 18, 2006), http://www.cfr.org/iran/syria-iran-mideast-conflict/p11122 ("Hezbollah receives some $\$ 100$ million per year from Tehran, and its Iranian-supplied weaponry is transported through Syria to Hezbollah's stronghold in Lebanon's southeast."). 
ak regime ${ }^{77}$ the presence of Iranian warships in the Mediterranean as a result of Egyptian permission to pass through the Suez Canal ${ }^{78}$ and permission to dock in Syria; ${ }^{79}$ unabated efforts to develop nuclear capability. ${ }^{80}$

\section{LIBYA AND SYRIA}

With this background in mind we turn our attention to the, perhaps unanswerable, riddle of how the U.S. distinguishes between the massacre of Libyans by their own government and the massacre of Syrians by their own government. With respect to the latter, as the Wall Street Journal commented, "Mr. Obama has kept a low profile [on Syria] . . . save to repeat his formulation that Mr. Assad ought to lead political reform or 'get out of the way." "81 The conflicts in both Syria and Libya are domestic in nature; the impetus is historical, pent-up enmity for murderous regimes that have brutally repressed civilians for decades. In Libya, Muammar Gadhafi ruled

76 See Greg Bruno, States Sponsors: Iran, CounCIL ON Foreign Relations (Oct. 13, 2011), http://www.cfr.org/iran/state-sponsors-iran/p9362 ("U.S. officials say Iran mostly backs Islamist groups . . a and Palestinian terrorist groups like Hamas . ...”).

77 See Barney Henderson, Hosni Mubarak Resigns: Mahmoud Ahmadinejad Hails 'a New Middle East,' THE TELEGRAPH (Feb. 11, 2011), http://www.telegraph.co.uk/news/worldnews /africaandindianocean/egypt/8319200/Hosni-Mubarak-resigns-Mahmoud-Ahmadinejadhails-a-new-Middle-East.html (describing Ahmadinejad's anti-Mubarak rhetoric and Iranian demonstrations against Mubarak).

78 See Ernesto Londono \& Thomas Erdbrink, Iran Officials Applaud Warships' Suez Transit, WAsh. Post, Feb. 23, 2011, at A6 (describing the February 2011 voyage of the Iranian frigate Alvand and an accompanying supply ship through the Suez Canal to a port in Latakia, Syria).

79 Id.; see also Syria, Iran Sign Naval Training Agreement, XINHUA News (Feb. 27, 2011), http://news.xinhuanet.com/english2010/world/2011-02/27/c_13751664.htm (describing the Iranian ships docking in Latakia and the signing of a training agreement between the two nations).

80 For discussions of Iran's nuclear program see Iran's Nuclear Program, N.Y. TIMES, http://topics.nytimes.com/top/news/international/countriesandterritories/iran/nuclear_progra m/index.html (last updated Jan. 11, 2012); Greg Bruno, Iran's Nuclear Program, CounciL ON FOREIGN RELATIONS (Mar. 10, 2010), http://www.cfr.org/iran/irans-nuclear-program/p 16811; Louis René Beres, The Case for Strikes Against Iran, CHRISTIAN SCI. Monitor (May 8, 2007), http://www.csmonitor.com/2007/0508/p09s01-coop.html; Louis René Beres, Expected Effects of an Iranian Nuclear Attack on Israel, SCHOLARS FOR PEACE MidDLE E. (June 5, 2011), http://spme.net/cgi-bin/articles.cgi?ID=8115.

81 See Assad's Embassy Raid, WALL ST. J. (July 12, 2011), http://online.wsj.com /article/SB10001424052702303812104576440022654206458.html. Obama to al-Assad: Embrace Democracy or 'Get Out of the Way,' CNN (May 19, 2011), http://articles. cnn.com/2011-05-19/world/syria.unrest_1_syrian-state-television-syrian-people-al-assad?_s =PM:WORLD; see Mark Landler \& David E. Sanger, White House, in Shift, Turns Against Syria Leader, N.Y. TimeS, July 13, 2011, at A4 (articulating the possible change in Obama Administration policy). 
since a successful coup in $1969 .{ }^{82}$ In Syria, as a result of a coup, Hafez elAssad ruled from 1970 till his death in 2000, whereupon his son, Bashar, replaced him. ${ }^{83}$

The Gadhafi regime had, in addition to brutally repressing its own population, engaged the West in terrorist attacks. The 1986 downing of PAN AM Flight $106,{ }^{84}$ resulting in the deaths of 270 passengers, is but the most egregious example; the killing of two U.S. servicemen in a German pub $^{85}$ resulted in President Reagan's decision to both attack Libyan ships in the Gulf of Sidra ${ }^{86}$ and to target Gadhafi. ${ }^{87}$ In the twenty five years thereafter, the U.S. and Libya have had an uneasy relationship which significantly improved in 2003 when Gadhafi announced abandonment of his nuclear plan. ${ }^{88}$ While long-considered unpredictable and, arguably, unstable, ${ }^{89}$ Gadhafi-since the Lockerbie bombing - had largely withdrawn from confrontation with the U.S., posing neither threat nor risk to Americans or American assets. Libyan oil reserves are important for Europe, which im-

82 Aidan Lewis, Profile: Muammar Gaddafi, BBC News AFrICA (June 27, 2011), http://www.bbc.co.uk/news/world-africa-12488278. Gadhafi was overthrown by a popular uprising and eventually killed on October 20, 2011. New Era, Challenges Loom for Libyans Free of Gadhafi, CNN (Oct. 21, 2011), http://www.cnn.com/2011/10/21/world/africa/libyanext/index.html?hpt=hp_t1.

83 President Hafez Assad's eldest son, Basil, was killed in a car accident in 1994. William E. Schmidt, Assad's Son Killed in Auto Crash, N.Y. Times (Jan. 22, 1994), http://www. nytimes.com/1994/01/22/world/assad-s-son-killed-in-an-auto-crash.html. As a result Bashar Assad, a trained ophthalmologist, was picked to replace his father. The Ophthalmologist Dictator: Syria's Bashar al-Assad, THE WEEK (May 27, 2011), http://theweek.com/article/ index/215645/the-ophthalmologist-dictator-syrias-bashar-al-assad.

84 The bombing is commonly referred to as the "Lockerbie Bombing" because the plane exploded over Lockerbie, Scotland. See Colonel Gaddafi 'Ordered Lockerbie Bombing,' BBC NEws S. SCOTLAND (Feb. 23, 2011), http://www.bbc.co.uk/news/uk-scotland-southscotland-12552587.

85 See Steven Erlanger, 4 Guilty in Fatal 1986 Berlin Disco Bombing Linked to Libya, N.Y. TIMES, Nov. 14, 2001, at A7.

${ }^{86}$ Apr. 14, 1986: U.S. Bombs Libya, HisTORY.COM, http://www.history.com/this-day-inhistory/us-bombs-libya (last visited Oct. 29, 2011).

87 See George J. Church, Targeting Gaddafi, Time (Apr. 21, 1986), http://www.time.com/ time/magazine/article/0,9171,961140,00.html.

88 See Sammy Salama, Issue Brief: Was Libyan WMD Disarmament a Significant Success for Nonproliferation?, NuClEAR Threat InITIATIVE (Sep. 1, 2004), http://www.nti.org/ analysis/articles/was-libyan-wmd-disarmament-success/ ("In a stunning declaration on December 19, 2003, the Libyan government announced its intention to fully disarm its weapons of mass destruction (WMD) arsenal.").

89 See Lee Ferran, Wikileaks on Gadhafi: Very Strange, Very Wily, ABC News (Feb. 22, 2011), http://abcnews.go.com/Blotter/wikileaks-lybia-moammar-gadhafi-strange-wily/story ?id=12971733 (describing American diplomats' observance and interpretations of various personal quirks and eccentricities of Gadhafi). 
ports nearly $85 \%$ of the oil produced in Libya. ${ }^{90}$ Based on totals from earlier this year, Libyan oil accounts for the following percentages of European oil imports: Italy $22 \%$, Austria $21 \%$, France $16 \%$, Greece $15 \%$, Spain $12 \%$, Portugal $11 \%$, United Kingdom $9 \%$, and Germany $8 \% .{ }^{91}$ However, the same cannot be said with respect to the U.S. which imports only $0.2 \%$ of its oil from Libya. ${ }^{92}$ In other words, America's relationship with Libya for the past 25 years is best defined as 'wary but distant' with almost no direct mutual interests at stake. ${ }^{93}$

Various American administrations have, over the years, made efforts to engage the Assad regime in Syria. The truce brokered by Secretary of State Kissinger between Israel and Syria in the aftermath of the 1973 Yom Kippur War ${ }^{94}$ has held ground; according to reliable reports not one violation has been reported by either side. ${ }^{95}$ Furthermore, Israeli Prime Minister Rabin suggested wide-reaching territorial concessions to President Assad including withdrawal of the Israel Defense Forces from the Golan Heights $^{96}$ and re-deployment to the northern edge of the Sea of Galilee (Lake Kinneret). ${ }^{97}$ The Clinton Administration was significantly involved in

90 Country Analysis Briefs: Libya, ENERGY INFO. ADMIN., http://www.eia.gov/cabs /libya/pdf.pdf (last updated Feb. 2011) ("According to the International Energy Agency (IEA) the vast majority (around 85 percent) of Libyan oil exports are sold to European countries ....").

91 See Europe Gets Most of Libya's Oil Exports, SEATtLe Times (Feb. 22, 2011), http:// seattletimes.nwsource.com/html/businesstechnology/2014299479_apusoilpriceslibya.html.

92 Petroleum \& Other Liquids, ENERGY INFO. AdMIN. (July 28, 2011), http://www.eia.gov /dnav/pet/hist/LeafHandler.ashx?f=a\&n=pet\&s=mcrimly1. (The U.S. imported 15,608,000 barrels of oil from Libya in 2010); Frequently Asked Questions: How Much Oil Does the United States Consume Per Year?, ENERGY INFO. ADMIN. (June 6, 2011), http://www.eia.gov /tools/faqs/faq.cfm?id=33\&t=6. (The U.S. consumes 6,990,000,000 barrels of oil per year). Dividing the number of total barrels consumed by the number of barrels imported from Libya produces a percentage figure of $0.2233 \%$.

93 For an extensive discussion of U.S.-Libyan relations since Libya became independent in 1951 see Background Note: Libya, U.S. DEP'T OF STATE (July 7, 2011), http://www.state.gov /r/pa/ei/bgn/5425.htm\#relations.

94 See Separation of Forces Between Israel and Syria, ISRAEL Ministry OF ForeIGN AFF. (May 31, 1974), http://www.mfa.gov.il/MFA/Peace+Process/Guide+to+the+Peace+Process /Israel-Syria+Separation+of+Forces+Agreement+-+1974.htm (containing the text of the agreement and a description of Secretary Kissinger's role in the negotiations).

95 See Martin Briens, Syria/Israel-UNDOF-Adoption of Resolution 1994, FR. MINISTRY OF FOREIGN AFF. (June 30, 2011), http://www.diplomatie.gouv.fr/en/article_imprim.php3?id_ article $=15935$ ("The ceasefire line between Israel and Syria has been the most stable border line in the region since 1974 and the agreement on disengagement.").

96 Israel seized the Golan Heights from Syria in the 1967 Six Day War. Regions and Territories: The Golan Heights, BBC NEws MiDDLE E. (Aug. 10, 2010), http://news.bbc.co.uk/2/ hi/middle_east/country_profiles/3393813.stm.

97 See The Israel-Syria Negotiations, IsRAEl Ministry of ForeIGn AFFAIRS (May 21, 2008), http://www.mfa.gov.il/MFA/Peace\%20Process/Guide\%20to\%20the\%20Peace\%20 
these talks, believing that Syria was a linchpin to peace in the Middle East. ${ }^{98}$ Israeli Prime Minister Barak also sought to diplomatically engage Assad under the auspices of the Clinton Administration, though ultimately to no avail. ${ }^{99}$ In spite of these failures, the U.S. and Syria enjoyed full diplomatic relations, though efforts to engage President Assad in peace talks have thoroughly failed. ${ }^{100}$

The brutally repressive regime of President Assad (the father) was made clear in the 1982 massacre in the Syrian town of Hamma; over 10,000 citizens were massacred when Assad ordered the Syrian army to squash a purported revolt against the regime. ${ }^{101}$ While the brutal nature of the regime (in addition to the Hamma massacre) was well known and documented, successive U.S. Presidents turned a "blind eye" in the name of larger interests and goals. ${ }^{102}$ In the context of this pragmatic policy, President Assad

Process/Israel-Syria\%20Negotiations (describing proposed concession of the Golan Heights); Frederic C. Hof, Mapping Peace Between Syria and Israel, U.S. Inst. PEACE (Mar. 2009), available at http://library.usip.org/articles/1012101.1042/1.pdf ("Among other things, withdrawal to the June 4, 1967, line would give Syria beachfront property on the northeastern quadrant of the Sea of Galilee, Israel's national reservoir.").

98 In a widely reported incident, President Assad kept U.S. Secretary of State Christopher waiting for several hours prior to a previously arranged meeting. Jed Babbin, Regime Change, Again: Work Undone in Syria, NAT'L Rev. OnLINE (Nov. 12, 2003), http://old. nationalreview.com/babbin/babbin200311120817.asp.

99 See Carol Migdalovitz, Cong. Res. Serv., Foreign AfF., Def., \& Trade Div., The Middle EAst PEACE TALKS 10 (2003) (detailing the deterioration of discussions between President Assad and Prime Minister Barak over several fundamental disagreements).

100 Compare Background Note: Syria, U.S. DeP'T OF StATE (Mar. 18, 2011), http://www. state.gov/r/pa/ei/bgn/3580.htm (noting that the U.S. has resumed diplomatic relations with Syria since 2009, and Jim Lobe, Washington Ends Its Diplomatic Embargo, IPSNEWS.NET (Mar. 3, 2009), http://ispnews.net/news.asp?idnews=45966 (detailing the thawing of U.S.Syrian relations, beginning with the dispatching of two senior officials to Damascus), and Holly Fletcher, State Sponsor: Syria, COUNCIL ON FOREIGN REL. (last updated Feb. 2008), http://www.cfr.org/syria/state-sponsor-syria/p9368 (noting Syria's status as a state sponsor of terror), with A Brief History of U.S.-Syrian Diplomatic Relations, EMBASSY U.S.: DAMASCUSSYRIA, http://damascus.usembassy.gov/about_the_embassy.html (last visited Jan. 4, 2012).

101 A Look Back at Syria's 1982 Crackdown, NPR (May 11, 2011), http://www.npr.org/ 2011/05/11/136214343/a-look-back-at-syrias-1982-crackdown; see also Thomas L. Friedman, Op-Ed., Hama Rules, N.Y. Times, Sep. 21, 2001, at A35 (describing the repressive government strategies of the Assad regime as "Hama Rules," which provide virtually no limitations on subduing opposition groups).

102 The U.S. applied the same pragmatic philosophy predicated on advancing strategic American interests to a wide range of U.S. allies both in the Middle East and world-wide. Compare U.S. Foreign Policy and Human Rights: Situating Obama, 33 HuM. RTS. Q. 767, 779 (2011) (describing the American political tendency to resort to pragmatism in weighing human rights issues against economic relationships) with Trade Act of 1974, Pub. L. No. 93618, § 402, 88 Stat. 1978, 2056 (1975) (codified as amended at 19 U.S.C. § 2432(a) (2006)) (noting the Jackson-Vanik Amendment's linking of the Soviet Union's most-favored-nation status to human rights and policy-related criteria). 
brutalized his people while negotiating with the U.S.; simply put, Syrian domestic affairs were an internal matter which the U.S. chose to ignore while focusing on broader geo-political considerations.

The U.S. "blind eye" policy regarding domestic policy—regardless of its repressive nature and inevitable human cost-reflects respect for the principle of national sovereignty. ${ }^{103}$ However, as documented above, the U.S. has repeatedly violated that principle when broader American interests are perceived to be at stake.

Which brings us to the question: why did the Obama Administration choose not to intervene in Syria in the spring and summer of 2011? How does the Obama Administration distinguish between Syria and Libya? Why does the extraordinary violation of human rights in the latter justify international intervention whereas the massacre of innocent civilians in the former does not? With respect to Syria, the Obama Administration has limited its response to largely meaningless rhetoric, some of it embarrassingly 'distant' and 'distracted.' Secretary of State Clinton's comments are but a telling example:

"Syria's future is up to the Syrian people," she said, "but of course the efforts by the opposition to come together to organize in order to articulate a political agenda is an important part of political reform."

In both Libya and Syria a brutal regime was deliberately torturing, imprisoning and killing its own citizens. In both cases, thousands of citizens were forced to flee their homes with the understanding that the regime would brook no dissent, giving open fire orders that enabled indiscriminate shooting by its army into crowds of individuals. In other words, both regimes were engaged in massacring their citizens. While tragically not a new development in the Middle East, the confluence of the Arab Spring, social media, ${ }^{105}$ and heightened international focus on the region drew greater media and public scrutiny regarding both regimes.

103 The protection of national sovereignty is a dominant theme in international relations and the development of international law. See generally G.A. Res. 50/172, U.N. Doc. A/RES/50/172 (Dec. 22, 1995) (affirming the principle of national sovereignty in electoral processes for protecting human rights); see also G.A. Res. 56/154, U.N. Doc. A/RES/56/154 (Feb. 13, 2002) (emphasizing the importance of national sovereignty and non-interference regarding internal electoral processes).

104 Sebnem Arsu, Clinton Chides Turkey on Rights Record, N.Y. TIMES, July 17, 2011, at A10.

105 See William Halal, The Arab Spring and the Technology Revolution, WORLD FUTURE SOCIETY (May 27, 2011), http://www.wfs.org/content/arab-spring-and-technology-revolution (recognizing the major role information technology, namely social media, played in accelerating the Arab Spring). 
In Libya, opponents of the regime took to the streets; while uncertainty existed regarding both the identity and organization of the rebels, ${ }^{106}$ the Obama Administration ${ }^{107}$ and NATO decided to intervene militarily on their behalf. ${ }^{108}$ In deciding to intervene, the U.S. ${ }^{109}$ and NATO directly engaged $^{110}$ the Gadhafi regime, with the former bearing the brunt of the responsibility. ${ }^{111}$ By the end of the month of August 2011, the U.S. had flown 5,316 sorties since April 1, a total that included 1,210 airstrike missions and 101 Predator drone strike missions. ${ }^{112}$ In addition, the U.S. was providing nearly $70 \%$ of the intelligence capabilities and refueling assets, ${ }^{113}$ and by July 31, 2011, had spent over $\$ 896$ million since the intervention began. ${ }^{114}$

106 See Andy Stone, Who Are Libya's Rebels?, NolanChart.com (Mar. 19, 2011), http://www.nolanchart.com/article8465_Who_are_Libya's_rebels.html (asserting that the rebels' identity is still unknown, however, Libyan rebels are grounded in principles of religious fundamentalism rather than liberal democracy).

107 President Obama deployed U.S. military forces to Libya without receiving congressional authorization under the 1973War Powers resolution. See Charlie Savage \& Mark Landler, White House Defends Continuing U.S. Role in Libya Operation, N.Y. TIMES, June 16, 2011, at A16 ("U.S. operations do not involve sustained fighting or active exchanges of fire with hostile forces, nor do they involve U.S. ground troops," rendering War Powers authorization unnecessary in the eyes of the Administration); see also Paul Starobin, Op-Ed., A Moral Flip-Flop? Defining 'War,' N.Y. TIMES, Aug. 7, 2011, at SR5 (illustrating the issue of framing the Libyan intervention through a critical examination of Department of State Legal Adviser Harold Koh's position on the applicability of the War Powers resolution).

108 See Paula Newton, NATO: Libya Mission Will Be to Protect, Not Arm, CNN (Mar. 28, 2011), http://articles.cnn.com/2011-03-28/world/libya.nato_1_nato-civilians-libya-mission? s=PM:WORLD (indicating that NATO's control of the Libyan operation increased during its early stages).

109 See Missy Ryan \& Alister Bull, Obama Says U.S. Role Limited as Libya Strikes Start, REUTERS (Mar. 20, 2011), http://uk.reuters.com/article/2011/03/20/uk-libya-usa-idUKTRE 72I47920110320 (indicating that despite the Obama Administration's state intent of having a limited military role in Libya, the United States initially dominated Libyan military operations).

110 See Josh Rogin, Exclusive: Top U.S. Admiral Admits We Are Trying to Kill Qaddafi, FOREIGN POL'Y (June 24, 2011), http://thecable.foreignpolicy.com/posts/2011/06/24/exclu sive_top_us_admiral_admits_we_are_trying_to_kill_qaddafi (describing the joint U.S.NATO mission objective of locating and eliminating Gadhafi).

111 See Daniel Sagalyn, U.S. Forces Lead Attack Against Libya in Operation 'Odyssey Dawn,' PBS NewSHOUR (Mar. 19, 2011), available at http://www.pbs.org/newshour/run down/2011/03/us-forces-lead-attack-against-libya-in-operation-audacity-dawn.html.

112 Luis Martinez, US Military Intervention in Libya Cost At Least $\$ 896$ Million, ABC NEws (Aug. 22, 2011), http://blogs.abcnews.com/politicalpunch/2011/08/us-military-inter vention-in-libya-cost-at-least-896-million-.html (tallying total cost as of Aug. 22, 2011).

113 United States Activities in Libya, FOREIGN POL'y 9, http://www.foreignpolicy.com/files /fp_uploaded_documents/110615_United_States_Activities_in_Libya_--_6_15_11.pdf (last visited Jan. 4, 2012) (providing a detailed overview of American operations in Libya compiled by the White House).

114 Martinez, supra note 112. 
U.S. government projections estimated that by September 30, 2011, the total U.S. Department of Defense expense of the intervention would reach \$1.104 billion. ${ }^{115}$

The stated purpose of the military engagement was to force Gadhafi to either step down or leave Libya; ${ }^{116}$ that mission has been accomplished. That achievement, however, does not resolve the core question this article seeks to address.

In stark contrast, while the U.S. forces engaged Libyan forces, President Assad continues - unabated and unhindered - to massacre innocent Syrians. ${ }^{117}$ The Syrian opposition ${ }^{118}$ does not seem to be organized, in contrast to Libyan rebels; similarly, the former do not appear to be armed to the extent the latter are. ${ }^{119}$ However, in both cases the regime is directly engaging in the massacre of civilians; doubtlessly, some have taken up arms against the government whereas others are innocent victims of a brutal regime. There is a distinct difference between the Syrian opposition and Libyan rebels: the former are not organized and are seemingly poorly armed (at best) whereas the latter are organized and have been able to sufficiently arm

115 United States Activities in Libya, supra note 113, at 14-15 (basing this projection on actual U.S. expenditures of approximately $\$ 715$ million through June 3, 2011).

116 Compare James Rowley, Top U.S. Republicans Question Purpose and Goals of Libya Military Mission, BLOOMBERG (Mar. 24, 2011), http://www.bloomberg.com/news/2011-0323/boehner-presses-obama-on-contradiction-between-u-s-un-goals-for-libya.html (noting President Obama's statement at the outset of the Libyan operation indicating regime change was a key mission objective), with Rogin, supra note 110 (describing the joint U.S.-NATO mission objective of locating and eliminating Gadhafi).

117 See Syria Unrest: Hama Army Raid Kills Dozens, BBC News MidDle E. (July 31, 2011), http://www.bbc.co.uk/news/world-14356722 (noting that while president Obama condemns the Syrian government's use of violence against civilians, the U.S. is engaging Syria in military action); see also Khaled Yacoub Oweis, Syrian Forces Press Hama Assault into Ramadan, REUTERS (Aug. 1, 2011), http://www.reuters.com/article/2011/08/01/us-syriaidUSTRE76T02020110801 (noting many civilian deaths attributed to the Syrian government); Nada Bakri, Syrian Tanks Move in to Retake Rebellious City, N.Y. TIMES, Aug. 4, 2011, at A1 (discussing international condemnation of the Syrian offensive, in particular from Syria's neighbor Turkey).

118 See Suleiman al-Khan \& Simon Cameron-Moore, Syria Opposition Group Form Council to Counter Assad, ReUTERS (July 16, 2011), http://www.reuters.com/article/2011/07/16 /us-syria-opposition-council-idUSTRE76F1W320110716 (describing how initial efforts to unite Syrian factions were impeded by sectarian sensitivities and fears); Katherine Zoepf, Long Repressed in Syria, an Internal Opposition Takes Shape, N.Y. TIMES, Apr. 28, 2011, at A12; Anthony Shadid, Syrian Military Mounts Assault on Another City, N.Y. TimeS, Aug. 8, 2011, at A12 (noting the independent character of the opposition tribes of eastern Syria).

119 See Chris Keeler, Moving Towards Civil War in Syria, A LoOK AT THE MiddLE E. (June 7, 2011), http://notesfromamedinah.com/2011/06/07/moving-towards-civil-war-in-syria/ (distinguishing Libya, where weapons were abundantly available to opposition forces, from Syria, where weaponry is substantially more scarce). 
themselves overthrow ${ }^{120}$ the Gadhafi regime. The same cannot be said for the Syrian opposition; the contrast is particularly compelling and tragic for Syrian refugees, who are literally pouring into Turkey in an effort to escape their own army. ${ }^{121}$

The dichotomy, then, is clear: an organized rebel group is receiving significant international military assistance; an unorganized opposition has barely received the traditional platitudes that accompany non-intervention in the face of extraordinary violations of human rights. Declarations that the Syrian regime has lost legitimacy ${ }^{122}$ are true, but they are just that, declarations; devoid of intervention, they are akin to whistling in the wind. That, however, is the essence of the Obama Administration's policy with respect to Syria: mere words. Needless to say, that is a far cry from the aggressive intervention policy with respect to Libya. A Syrian escaping into Turkey just meters ahead of a Syrian bulldozer must be dumbfounded to hear the language of President Obama's Cairo speech ${ }^{123}$ and to see the U.S. air force aggressively attack Libyan targets.

Herein lies the rub: a compelling argument can be made that unorganized Syrians are in greater need of international intervention than organized Libyan rebels. That is, the U.S. and NATO have deliberately turned their back on the citizens of one country while readily coming to the assistance of the citizens of another country. Similarities far outweigh differences: two brutal regimes in the Middle East attacking their citizens in the shadow of the Arab Spring, and yet two distinct approaches. While the political considerations-Administration comments notwithstanding-are

120 Libyan Opposition Claims Major Gains, AL JAZEERA (July 21, 2011), http://english. aljazeera.net/news/africa/2011/07/201172161918114981.html (noting that Libya's opposition fighters have made significant territorial gains); Libyan Opposition Gains as Casualties Rise, InVESTIGATIVE PROJECT ON TERRORISM (Feb. 23, 2011), http://www.investigative project.org/2622/libyan-opposition-gains-as-casualties-rise (indicating that despite rising casualties, Libyan opposition forces were successfully consolidating control over the country).

121 The Syrian-Turkish border is worth closely watching; it is unclear what the response of the Turkish army would be if the Syrian army at the border to aggressively prevent additional Syrian's from flooding into Turkey. See Owen Bennett-Jones, Syria Crisis: Refugees in Turkey Fear for Jisr al-Shughour, BBC NEws MidDLE E. (June 9, 2011), http://www.bbc. co.uk/news/world-middle-east-13714168 (highlighting the exodus of Syrian refugees into Turkey).

122 See Clinton Says Assad Has 'Lost Legitimacy,' AL JAZEERA (July 12, 2011), http://english.aljazeera.net/news/middleeast/2011/07/201171204030379613.html (stating that the U.S. has nothing invested in Assad remaining in power); US Senators: Syria's Assad Has Lost His Legitimacy, YALIBNAN (May 12, 2011), http://www.yalibnan.com/2011/05/12/ussenators-syria\%E2\%80\%99s-assad-has-lost-his-legitimacy/ (describing how U.S. condemnation has evolved into a Senate resolution calling for "tough" action against the Syrian government).

123 New Beginning Speech, supra note 4. 
unclear, it is to the principle of humanitarian intervention that this article now turns.

\section{LAW OF HUMANITARIAN INTERVENTION}

As Professor Ryan Goodman asked, "Should international law permit states to intervene militarily to stop a genocide or comparable atrocity without Security Council authorization?"124 According to Article 39, Chapter VII of the U.N. Charter:

The Security Council shall determine the existence of any threat to the peace, breach of the peace, or act of aggression and shall make recommendations, or decide what measures shall be taken in accordance with Articles 41 and 42 , to maintain or restore international peace and security. ${ }^{125}$

While the U.N. authorized military force against Libya, ${ }^{126}$ it has not done so regarding Syria. ${ }^{127}$ Does that mean the U.S. cannot intervene in Syria? As Professor Goodman and others have written, ${ }^{128}$ international humanitarian intervention raises legitimate questions regarding pretext to "wage wars for ulterior motives." 129 From the perspective of international law, a discussion regarding international humanitarian intervention requires carefully analyzing the relationship between national sovereignty, international responsibility, and grave violations of human rights. The pretext argument suggested by Professor Goodman is of justifiable concern when examining specific examples of intervention; in the two examples discussed

124 Ryan Goodman, Humanitarian Intervention and Pretexts for War, 100 AM. J. INT'L L. 107, 107 (2006).

125 U.N. Charter art. 39.

126 Jay Solomon, Adam Entous \& Joe Lauria, U.N. Clears Way for Attack on Libya, WALL ST. J. (May 18, 2011), http://online.wsj.com/article/SB1000142405274870381820457620637 3350344478.html (noting that the U.N. Security Council authorized military force against Libya).

127 U.N. Security Council Issues Statement Condemning Violence in Syria, CNN (Aug. 3, 2011), http://www.cnn.com/2011/WORLD/meast/08/03/syria.unrest/index.html?hpt=hp_t1 (noting that thus far, the U.N. Security Council has only issued a statement condemning the violence in Syria).

128 Goodman, supra note 124; see, e.g., Jacob Katz Cogan, The Regulatory Turn in International Law, 52 HARV. INT'L L.J. 321 (2011) (purporting that there has been an unnoticed change in international regulatory law allowing for states who treat their citizens improperly to come under international scrutiny); Jonah Eaton, An Emerging Norm? Determining the Meaning of Legal Status of the Responsibility to Protect, 32 Мich. J. INT’L L. 765 (2011) (discussing the emerging norm in the U.N. General Assembly to protect during humanitarian intervention); Nicholas Lamp, Conceptions of War and Paradigms of Compliance: The 'New War' Challenge to International Humanitarian Law, 16 J. CONFLICT \& SECURITY L. 225 (2011) (arguing that modern new wars pose challenges to international humanitarian law).

129 Goodman, supra note 124. 
in this essay, the application of international humanitarian intervention principles reflects the inconsistency previously referenced.

Humanitarian intervention is an inherently complicated proposition, because it clearly implies both that nation state ' $A$ ' is engaged in significant violations of the human rights of its own citizens, requiring nation state ' $\mathrm{B}$ ' and/or the international community to recognize that intervention is essential. ${ }^{130}$ However, analysis of when intervention is deemed essential and criteria justifying intervention suggest an enormous lack of clarity and lack of objective standards and benchmarks.

The lack of clear criteria as to when intervention is justified, if not required, suggests that the question is one of interpretation, subject to specific circumstances and particular interests. ${ }^{131}$ In that vein, then, the question-relevant to the discussion of this essay-is: why does the U.S. not determine that the actions of the Syrian government justify international humanitarian intervention? As of January 2012, the Syrian death toll was estimated to exceed five thousand people. ${ }^{132}$ In addition to the rising death toll, anywhere between 15,000 to 40,000 protestors have been reported missing or in Syrian custody since the protests began. ${ }^{133}$ In fact, a high-level U.N. human rights team recently released a report finding systematic human rights violations by the Syrian government, including summary executions, prisoner torture, and targeting children during the government's crackdown on opposition protestors. ${ }^{134}$ Based on its findings, the U.N. team ultimately

130 See Learn about the International Coalition for the Responsibility to Protect, INT'L COAL. FOR RESP. TO PROTECT, http://www.responsibilitytoprotect.org/index.php/aboutcoalition (last visited July 14, 2011) (detailing an effort to impose a normative standard for demanding preventative intervention).

131 Compare Chris Borgen, The "Libya and Humanitarian Intervention" Meme, OPINIO JURIS (Feb. 24, 2011), http://opiniojuris.org/2011/02/24/the-libya-and-humanitarian-interv ention-meme/ (compiling internet responses related to the humanitarian intervention in Libya), and Asli Ü. Bali \& Ziad Abu-Rish, On International Intervention and the Dire Situation in Libya, JADALIYYA (Feb. 23, 2011), http://www.jadaliyya.com/pages/index/725/on-inter national-intervention-and-the-dire-situation-in-libya (advocating for solutions to the situation and Libya and describing the condemnation of the violence in Libya), with Issandr El Amrani, A Different Take On Foreign Intervention in Libya, ARABIST (Feb. 24, 2011), http://www.arabist.net/blog/2011/2/24/a-different-take-on-foreign-intervention-in-libya.html (opposing foreign military intervention), with Shadi Hamid, Libya Uprising: It's Time to Intervene, SLATE (Feb. 23, 2011), http://www.slate.com/id/2286184/ (giving the international community options for supporting a regime change in Libya).

132 Syria - Protests, N.Y. TIMES, http://topics.nytimes.com/top/news/international/countries andterritories/syria/index.html (last updated Jan. 11, 2012).

133 Id.

134 U.N. Human Rights Council, Rep. of the U.N. High Comm'r for Human Rights on the Situation of Human Rights in the Syrian Arab Republic, II 22, U.N. Doc. A/HRC/18/53; GAOR, 18th Sess. (Sept. 15, 2011) (listing human rights violations in Syria); see also Frank Jordans, U.N. Syria Mission Finds Systematic Human Rights Violations, HufFInGTON Post 
recommended that Syria be referred to the International Criminal Court for prosecution of the alleged atrocities. ${ }^{135}$ By comparison, the Libyan death toll was estimated at over 1,000 on February $23,2011,{ }^{136}$ only weeks before the U.N. authorized intervention in Libya ${ }^{137}$ and NATO began flying sorties over the country. ${ }^{138}$

Precisely because international law does not articulate either normative or architectural standards as to when international humanitarian intervention is justified, national leaders arguably have a responsibility to act. ${ }^{139}$ The oft-cited phrase "when the cannons roar, the muses are silent" 140 is particularly relevant to this discussion. For a variety of reasons, the international community has determined-whether actively or passively - that the massacre of the Syrian population by the Assad government does not justify international humanitarian intervention. While the human rights violations occurring on a daily basis do not compare to the horrors of Rwanda, ${ }^{141}$ Kosovo, ${ }^{142}$ or Sierra Leone ${ }^{143}$ they are not less compelling than the events tran-

(Aug. 18, 2011), http://www.huffingtonpost.com/2011/08/18/un-syria-hman-rights_n_ 930577.html.

135 See U.N. Human Rights Council, supra note 134, II 94(c); see also Jordans, supra note 134.

136 Rachel Donadio, Italy Says Death Toll Is Likely Over 1,000, N.Y. TIMES (Feb. 23, 2011), http://www.nytimes.com/2011/02/24/world/europe/24italy.html.

137 Dan Bilefsky \& Mark Landler, Military Action Against Qaddafi is Backed by U.N., N.Y. Times, Mar. 18, 2011, at A1.

138 Libya Profile: Timeline, BBC NEws AFRICA, http://news.bbc.co.uk/2/hi/africa/13984 37.stm (last updated Dec. 1, 2011) (chronicling the start of NATO airstrikes in Mar. 2011).

139 See Jayshree Bajoria, Libya and the Responsibility to Protect, COUNCIL ON ForEIGN REL. (Mar. 24, 2011), http://www.cfr.org/libya/libya-responsibility-protect/p24480 (stating if a state fails to protect its citizens from genocide or other war crimes, it becomes the international community's responsibility to do so); Irwin Cotler \& Jared Genser, Libya and the Responsibility to Protect, N.Y. TIMES (Feb. 28, 2011), http://www.nytimes.com/2011/03/01/ opinion/01iht-edcotler01.html?_r=2 (authorizing action from the international community to protect a state's population from genocide or other war crimes if that state is unable or unwilling to protect its citizens, or if that state is the perpetrator of such actions at a U.N. world summit in 2005); The Crisis in Syria, InT'L COAL. FOR THE RESP. TO ProteCt, http://www. responsibilitytoprotect.org/index.php/crises/crisis-in-syria (last visited Jan. 4, 2012) (discussing alleged human rights violations by the Syrian government and calling for intervention by the international community).

140 Cicero, Pro Milone 11 (A.B. Poynton ed., 2nd ed. 1902).

141 See Bureau of Democracy, Human Rights, and Labor, 2009 Human Rights Report: Kosovo, U.S. DEP'T OF STATE (Mar. 11, 2010), http://www.state.gov/g/drl/rls/hrrpt/2009 /af/135971.htm.

142 The death toll in Kosovo was estimated between 5,000 and 12,000. See $Q$ \& A Counting Kosovo's Dead, BBC News (Nov. 12, 1999), http://news.bbc.co.uk/2/hi/europe/517168.stm. For a more recent report, see Bureau of Democracy, Human Rights, and Labor, 2009 Human Rights Report: Kosovo, U.S. DEP'T OF STATE (Mar. 11, 2010), http://www.state.gov/g/drl/rls/ hrrpt/2009/eur/136039.htm. 
spiring in Libya. If, by metaphorical analogy, the international community is the cannons and the U.S. is the muse, does that mean that the Obama Administration is required to be silent? After all, if the quote were to be rigorously applied, then many of the institutions created to minimize human suffering would neither exist, much less function in wartime. ${ }^{144}$ While the distinction - from the perspective of international humanitarian intervention-between Libya and Syria is as unclear, as are the criteria that justify intervention, that must not serve as a misguided basis for the Obama Administration to largely turn its back on the Syrian people.

\section{FINAL WORD}

The lack of precise international law criteria articulating when intervention is mandated must not serve as a convenient 'out' for the U.S. As described in detail above, the Middle East is presently in a state of extraordinary flux; uncertainty and dramatic change are the contemporary reality. Inherent to those is danger, significant human rights violations, and remarkable instability. In addition, a direct result of President Obama's Cairo speech and subsequent comments is the expectation that the U.S. will play a decisive role in the Middle East, reflecting attitudes and philosophies distinct from previous administrations. And yet, when given the opportunity to decisively and consistently act in a region of the world whose primary characteristics are instability and inconsistency, President Obama-in the Syrian context-blinked.

The Arab world's profound disappointment with President Obama ${ }^{145}$ is, frankly, justified and disconcerting. President Obama has no one to blame but himself for this development. The disappointment is justified because, as the phrase goes, the bigger the expectation, the bigger the disappointment; it is disconcerting because there is no vacuum in the Middle East and powerful voices and forces of violence pose a threat to the region and world alike. Inconsistent foreign policy-particularly in a region of the world as volatile as the Middle East - is a luxury U.S. interests cannot brook. In other words, the law's uncertainty does not justify policy incon-

143 See Bureau of Democracy, Human Rights, and Labor, 2009 Human Rights Report: Sierra Leone, U.S. DEP'T OF STATE (Mar. 11, 2010), http://www.state.gov/g/drl/rls/hrrpt/ 2009/af/135975.htm.

144 See generally Amos N. Guiora \& Erin M. Page, Going Toe to Toe: President Barak's and Chief Justice Rehnquist's Theories of Judicial Activism, 29 Hastings InT'L \& COMP. L. REV. 51 (2005) (addressing the role of judicial review in times of conflict).

145 See Glenn Greenwald, US More Unpopular in the Arab World than Under Bush, SALON (July 13, 2011), http://www.salon.com/news/middle_east/index.html?story=/opinion/green wald/2011/07/13/arabs (describing unfavorable attitudes towards the U.S. during the Obama administration when favorable attitudes dropped to levels lower than they were during the last year of the Bush Administration). 
sistency, particularly when Syrian citizens are suffering no less than Libyan citizens. In both paradigms, two repressive, historically brutal regimes that have long violated basic human rights are, once again, killing their own citizens. And yet, the powerful similarities notwithstanding, the Obama Administration has adopted two distinct responses to what are, in essence, mirror paradigms.

In the context of providing much needed-actually critically required-humanitarian intervention, the President has failed the Syrian people. While the Administration has intensified its rhetoric ${ }^{146}$ regarding the Syrian regime, words do not, and never have, provided actual assistance to those subjected to indiscriminate open fire orders with live ammunition. Perhaps words may satisfy the speaker, but to the victims, they are just words. While they can create expectation, and subsequent disappointment, they are not a substitute for action.

Some will query, and legitimately so, why it is the U.S. that must come to the assistance of the Syrian population. Obviously, the French and British have the capability, resources and historical relationship to the Middle East. However, neither President Sarkozy nor Prime Minister Cameron promised the people of the Middle East a new dawn; neither stood in Cairo and created the expectations that President Obama did. In addition-as a reality of contemporary geo-politics - in the aftermath of the fall of the Berlin Wall, there is only one superpower in the world today. To be a superpower requires both military and moral leadership.

Criteria regarding international humanitarian intervention are unclear; however, the situation in Syria is clear. Nevertheless, the ambiguity surrounding whether/when a domestic crisis justifies international humanitarian intervention need not contribute to policy that is clearly at loggerheads with itself. That is, while the law is unclear, President Obama's polices are similarly unclear. What is clear, however, is that the Syrian government is massacring its citizens in a manner similar to the Libyan government. Evidently, the similarity ends there, for the actions of the Obama Administration are fundamentally different with respect to the two coun-

146 See Elizabeth Flock, Obama: Syria's Assad Must Go, WASH. Post Blogs (Aug. 18, 2011, 12:57 PM), http://www.washingtonpost.com/blogs/blogpost/post/obama-it-is-time-forsyrias-assad-to-go/2011/08/18/gIQABPVpNJ_blog.html (explaining that President Obama issued a symbolic statement followed by a more meaningful executive order); Joshua Hersh, Obama: Syrian President Assad Must Step Down, HufFIngton Post, http://www.huffington post.com/2011/08/18/obama-assad_n_930229.html (last updated Oct. 18, 2011) (recounting President Obama's demand that President Assad step down); Obama: Syria Must Stop 'Murder and Mass Arrest' of Citizens, BBC News (May 19, 2011), http://www.bbc.co.uk/news /world-us-canada-13464011 (presenting President Obama's call for Assad to allow for peaceful protests); Another Obama Warning On Syria: 'I Am Appalled,' L.A. TIMES (July 31, 2011), http://latimesblogs.latimes.com/washington/2011/07/obama-syria-violence.html (reprinting statement by President Obama). 
tries. Needless to say, that is the President's prerogative; nevertheless, the dissonance is jarring, both philosophically and practically.

Deciphering the President's policy is proving as complicated as establishing international standards justifying intervention. However, while the former can be subject to continuous academic debate, the human rights violations that define Syria today cannot be addressed by mere rhetoric, even if forceful. The President has an opportunity to apply the principles of international humanitarian intervention in a manner that will restore confidence in his leadership and set a clear example of consistency and stability. That is particularly important in a region of the world that is, at the moment, a most dangerous powder keg of extraordinary instability and danger. 